\title{
Assessment of Volatile Oil Composition, Phenolics and Antioxidant Activity of Bay (Laurus nobilis) Leaf and Usage in Cosmetic Applications
}

\author{
Şeyda KIVRAK ${ }^{1 *}$, Tolga GÖKTÜRK ${ }^{2}$, İbrahim KIVRAK ${ }^{2}$
}

\author{
${ }^{1}$ Department of Nutrition and Dietetics, Faculty of Health Sciences, Muğla Sitk1 Koçman University, Muğla, \\ Turkey \\ ${ }^{2}$ Department of Chemistry and Chemical Treatment Technologies, Muğla Vocational School of Higher Education, \\ Muğla Sitkı Koçman University, Muğla, Turkey
}

Received: May 31, 2017 - Revised: June 16, 2017 - Accepted: June 242017

\begin{abstract}
In this study, the components of the volatile oil obtained from Laurus nobilis leaves by steam distillation were determined using Agilent 6890 Gas Chromatography (GC) - 5975 Mass Spectrometry (MS). The antioxidant activities of different extracts of $L$. nobilis leaves were determined by using DPPH ${ }^{\cdot}$ (2,2-diphenyl-1picrylhydrazyl) free radical scavenging activity, $\beta$-carotene-linoleic acid bleaching assay and ABTS $^{\bullet+}\left(2,2^{\prime}\right.$-azinobis(3-ethylbenzothiazoline-6-sulphonic acid) cation radical decolorization assay. Determination of the total phenolic contents of $L$. nobilis leaf extracts were performed using the Folin-Ciocalteau procedure and total flavonoid contents were measured using a spectrophotometric assay. According to the GC/MS results, 1,8-cineole (46.16\%), alpha-terpinyl acetate (10.62\%), alpha-pinene $(6.27 \%)$, terpinen-4-ol $(5.07 \%)$ and sabinene $(4.99 \%)$ were found to be the major compounds in volatile oil. The obtained volatile oil was used to make skin care lotion. Stability tests and organoleptic analyses of final product were performed after 1, 5, 30 and 90 days of production. The highest amounts of total flavonoid content were found to be $5.48 \pm 0.65$ and $8.60 \pm 0.12 \mu \mathrm{g}$ QEs/mg in ethyl acetate and ethanol extracts, respectively. The highest amounts of total phenolic compounds were found to be $54.42 \pm 0.14$ and $25.32 \pm 0.10 \mu \mathrm{g}$ PEs/mg in ethyl acetate and ethanol extracts, respectively. According to the results of $\mathrm{ABTS}^{\cdot+}$, $\mathrm{DPPH}^{*}$ and $\beta$-carotene linoleic acid assays, ethyl acetate extract was found to be the most active extract $\left(24.98 \pm 0.87 \mu \mathrm{g} \mathrm{mL}^{-1}, 75.65 \pm 0.77 \mu \mathrm{g} \mathrm{mL}^{-1}\right.$ and $\left.19.32 \pm 1.04 \mu \mathrm{g} \mathrm{mL}^{-1}\right)$.
\end{abstract}

Keywords: Laurus nobilis, Volatile oil, Antioxidant, Cosmetic, GC/MS

\section{Introduction}

Volatile oils are secondary plant metabolites, which are found in different parts of plants including flowers, roots, bark, leaves, seeds, peel, fruit and wood produced in cytoplasm and plastids of plant cells [1]. These oils, also known as essential oil, etheric oil by people, can contain terpenic hydrocarbons and their oxygenated derivatives as well as organic acids, alcohols, phenols and ketones [2]. The main components of volatile oils are usually mono and sesquiterpenes. In some cases their main derivatives are hydrocarbons (e.g. turpentine, formed

\footnotetext{
*Corresponding Author E-mail: skivrak@mu.edu.tr tolgagokturk@mu.edu.tr ikivrak@mu.edu.tr 
by alpha and beta-pinene), while in others the main constituents are oxygenated (e.g. cloves formed by eugenol) [3,4]. Some of the aromatic plants have a volatile oil formed mainly of aromatic compounds derived from allyl or isoallyl phenol. The plants containing those compounds, although they are less frequent than plants containing terpenes, only allow such compounds to be selective.

There has always been a great deal of interest in volatile oils throughout history. Although many of the intended uses of volatile oils have disappeared over time, it has generally been accepted that since the beginning of mankind, humans have obtained these oils from aromatic plants. Volatile oils have various applications for different purposes. Volatile oils are not only used for cooking in order to improve the taste and health of the food, but also for the manufacture of perfumes and cosmetic products [5].

The ancient Egyptians have used volatile oils in perfumery, medicine and even in the preparation of bodies and organs for mummification. In ancient Asia, Vedas coded intended uses of perfume and aromatics for therapeutic purposes. Indeed, throughout history, many civilizations have used volatile oils and fragrances for a variety of purposes, including religious rituals, perfumes and therapeutic against infectious diseases. During the Renaissance period, the use of volatile oils in perfumery and cosmetic products has been spread to the world [6].

Volatile oils can be obtained by water distillation, water and steam distillation, or steam distillation alone, which are the most commonly used methods. The part of the plant where the volatile oil is to be obtained may be fresh, partially or completely dried, but if the volatile oil is to be obtained from the flower part, the flowers should be fresh [7].

Different methods have been used to control and analyze essential oils [8]. Currently, however, the identification of essential oil components is usually carried out with the aid of gas chromatography-mass spectrometry (GC/MS) equipped with flame ionization detector (FID) and mass spectrometer (MS) detectors, a capillary column and a split. Test conditions may vary depending on the column and the sample [9].

The main sources of volatile oils are medicinal and aromatic plants, which are widely used since ancient times in medicine, cosmetics and preserving and improving the flavor of foods. Especially in recent years, there are numerous artificial chemical-free productions, mainly cosmetics, due to the increased interest in natural products [10]. As a natural ingredient, volatile oils are a growing market trend, being used in skin care cosmetics (e.g creams, lotions), balms, shampoos, soaps and perfumes [11].

Laurus nobilis (Lauraceae), one of the main sources of plant volatile oils, is an evergreen shrub that can grow up to 8 meters tall. It has dark green leaves about $8-14 \mathrm{~cm}$ long and $3-4 \mathrm{~cm}$ wide $[12,13]$.

This plant, belonging to Lauracea family and unique to the southern Mediterranean region, is widely grown in Europe and USA as an ornamental plant. It is cultivated commercially for aromatic oil, found in its leaves, in Turkey, Algeria, Morocco, Portugal, Spain, Italy, France and Mexico. Turkey is the leader bay leaf exporter of the World. [14].

The volatile oils obtained from the leaves of L. nobilis still maintains the importance in both traditional and modern medicine with its pharmacological activities. Studies have shown that L. nobilis volatile oil has antioxidant [15], anticonvulsant [16], analgesic, antiinflammatory [13], antiviral [17], anticholinergic [18], antibacterial [19] and antifungal activities [20]. L. nobilis, which is a powerful medicinal and aromatic plant with these pharmacological properties, has been reported in cosmetic uses. L. nobilis leaf volatile oil is used for the preparation of hair lotion due to its antidandruff activity and for the treatment of psoriasis [21]. 
The usage of volatile oils in the production of cosmetics and similar products can both increase the dermo-cosmetic effects of these products and marketing trend for the final product. A great number of usages of plant materials such as volatile oils in cosmetics products provide extra benefits to the skin more than ordinary products. [22].

In this study, the chemical composition of L. nobilis leaf volatile oil was examined using GC/MS. The antioxidant activities of different extracts of $L$. nobilis leaves were determined by using DPPH $^{*}$ (2,2-diphenyl-1-picrylhydrazyl) free radical scavenging activity, $\beta$-carotenelinoleic acid bleaching assay and $\mathrm{ABTS}^{-+}$(2,2'-azino-bis(3-ethylbenzothiazoline-6-sulphonic acid) cation radical decolorization assay. Determination of the total phenolic contents of $L$. nobilis leaf extracts performed using the Folin-Ciocalteau procedure and total flavonoid contents were measured using a spectrophotometric assay. In addition, we prepared skin lotion using the volatile oil obtained with steam distillation. After preparation of lotion, we performed stability tests and organoleptic tests on the final product.

\section{MATERIALS AND METHODS}

\subsection{Standards and Reagents}

Ethanol, n-hexane, methanol, ethyl acetate and chloroform were of analytical grade purity were supplied by Merck (Darmstadt, Germany). Essential oil standards were supplied from Sigma-Aldrich Chemie GmbH, Steinheim, Germany. Water was HPLC grade (18.2 M $\Omega$ ), purified by a Milipore Milli-Q (Molsheim, France) system that includes reverse osmosis, ion exchange and filtration steps. $\beta$-carotene, tween-40, 2,2-diphenyl-1-picrylhydrazyl ( $\mathrm{DPPH} \mathrm{H}^{*}$ ), 2,2'-Azino-bis-3-ethylbenzthiazoline-6-sulfonic acid $\left(\mathrm{ABTS}^{\circ+}\right)$, potassium persulfate $\left(\mathrm{K}_{2} \mathrm{~S}_{2} \mathrm{O}_{8}\right)$, linoleic acid, butylated hydroxytoluene (BHT), butylated hydroxyanisole (BHA), poly(acrylic acid sodium salt), alpha-tocopherol were obtained from Sigma-Aldrich Chemie $\mathrm{GmbH}$ (Steinheim, Germany). All other chemicals and solvents were of analytical grade and purchased from usual suppliers.

\subsection{Plant Material and Isolation of Volatile Oil}

Laurus nobilis leaves were collected in June 2016 from the trees in Fethiye region of Muğla (Turkey). Authentication of the plant was performed by Dr. Ergun KAYA from Department of Molecular Biology and Genetics, Faculty of Science, Muğla Sitkı Koçman University, Muğla (Turkey). Collected leaves were dried under ambient temperature $\left(25^{\circ} \mathrm{C}\right)$, shadow and airy place. Dry leaves were separated from the vimen.

Air-dried leaves of L. nobilis subjected to steam distillation for $120 \mathrm{~min}$ to obtain its volatile oil. The resulting volatile oil was dried over anhydrous sodium sulphate, filtered and stored in a dark glass bottle at $-21^{\circ} \mathrm{C}$ until analyze by Gas Chromatography-Mass Spectrometry (GC/MS).

\subsection{Determination of Chemical Composition of Volatile Oil Using GC/MS}

GC/MS analyses were carried out using an Agilent 6890N Gas Chromatograph equipped with a Multi Mode Inlet $(\mathrm{MMI})\left(280^{\circ} \mathrm{C}\right)$, a DB-1 capillary column $(30 \mathrm{~m} \times 0.25 \mathrm{~mm}$; film thickness $0.25 \mu \mathrm{m}$ ) and coupled with an Agilent 5975C MS Detector (MSD), operating in the electron impact (EI) mode at $70 \mathrm{eV}$. Transfer line temperature was set at $250^{\circ} \mathrm{C}$. The carrier gas was $\mathrm{He}(2.1 \mathrm{~mL} / \mathrm{min})$, and the oven temperature was held at $60^{\circ} \mathrm{C}$ for $5 \mathrm{~min}$, then increased up to $220^{\circ} \mathrm{C}$ at a rate of $2^{\circ} \mathrm{C} / \mathrm{min}$ and held at this temperature for $10 \mathrm{~min}$. The injected volume was $2 \mu \mathrm{L}$ and the split ratio $40: 1$.

In this study, the identification of the compounds was based on the comparison of their retention times (RT) and mass spectra with those from the NIST 2008, Wiley 2008 and Flavor2 
libraries. Relative percentages of compounds were calculated based on the peak areas from the MS data.

\subsection{Determination of Antioxidant Activities}

\subsubsection{Preparation of Extracts}

In the determination of antioxidant activities of $L$. nobilis leaf, four different extracts, hexane, ethyl acetate, ethanol and water, were used. The sample was extracted five times for 24 hours at room temperature with hexane, ethyl acetate, ethanol, water and then the combined extracts were filtered through Whatman No 4, separately. The combined extracts of hexane, ethyl acetate, and ethanol were evaporated (rotary evaporator Heidolph, Hei-VAP Precision) to dryness in vacuum, and the combined water extracts were lyophilized (Christ Freeze Dryer, Alpha 1-4 LD plus, Germany). The extracts were stored in deepfreeze until the time of study. The results were given as $50 \%$ inhibition concentration $\left(\mathrm{IC}_{50}\right)$. The sample concentration $\left(\mu \mathrm{g} . \mathrm{mL}^{-1}\right)$ inhibiting $50 \%$ antioxidant activity $\left(\mathrm{IC}_{50}\right)$ was calculated from the graph of activity percentage against sample concentration.

\subsubsection{DPPH* Free Radical Scavenging Assay}

The free radical scavenging activity of $L$. nobilis leaf extracts was determined using the method, $\mathrm{DPPH}^{*}$ free radical protocol [23] with slight modifications. The extract solutions prepared in different concentrations $(40 \mu \mathrm{L})$ and ethanolic solution $(120 \mu \mathrm{L})$ containing $\mathrm{DPPH}^{\circ}$ radicals $(0.4 \mathrm{mM})$ were incubated in darkness at room temperature for $30 \mathrm{~min}$. Absorbance was measured at $517 \mathrm{~nm}$ in SpectraMax 340 PC, Molecular Device (USA). The radical-scavenging activity (RSA) was calculated as a percentage of $\mathrm{DPPH}^{\circ}$ decolorization using the following equation:

$\% \mathrm{RSA}=\left[\left(\mathrm{A}_{\mathrm{DPPH}}-\mathrm{As}_{\mathrm{S}}\right) / \mathrm{A}_{\mathrm{DPPH}}\right] \times 100$

Where $A_{S}$ is the absorbance of the solution containing the sample and $A_{D P P H}$ is the absorbance of the DPPH' solution.

\subsection{3. $\beta$-Carotene-Linoleic Acid Bleaching Assay}

The total antioxidant activity was determined using $\beta$-carotene-linoleic acid test system based on the detection of inhibition of conjugated dien hydroperoxides due to oxidation of linoleic acid $[24,25]$. $\beta$-Carotene $(0.5 \mathrm{mg})$, dissolved in $1 \mathrm{~mL}$ of chloroform, was mixed with linoleic acid $(25 \mu \mathrm{L})$ and Tween 40 emulsifier $(200 \mathrm{mg})$. Chloroform was evaporated under low pressure, $50 \mathrm{~mL}$ of distilled water was added by vigorous shaking. Aliquots $(1.60 \mu \mathrm{L})$ of this emulsion were added to $40 \mu \mathrm{L}$ of the extract solutions at different concentrations. As soon as the emulsion was added to each tube, the zero time absorbance was initially measured at 470 $\mathrm{nm}$, and then the absorbance measurements were done for every $30 \mathrm{~min}$ until $120 \mathrm{~min}$.

\subsubsection{ABTS $^{\circ+}$ Cation Radical Decolorization Assay}

The spectrophotometric analysis of $\mathrm{ABTS}^{\bullet+}$ scavenging activity was determined according to the previously described method [26]. The $\operatorname{ABTS}^{\cdot+}(7 \mathrm{mM})$ in water and potassium persulfate $(2.45 \mathrm{mM})$ reacted to give $\mathrm{ABTS}^{\circ+}$, stored in the dark at room temperature for $12 \mathrm{~h}$, and oxidation of $\mathrm{ABTS}^{\circ+}$ appeared immediately, however, the stability of absorbance was gained after $6 \mathrm{~h}$. Then, the sample solution $(40 \mu \mathrm{L})$ in ethanol at different concentrations were mixed with $\mathrm{ABTS}^{\circ+}$ solution $(160 \mu \mathrm{L})$, giving the absorbance at $734 \mathrm{~nm}$ by using a 96 -well microplate reader in 10 minute. The scavenging capability of $\mathrm{ABTS}^{\cdot+}$ was calculated using the following equation:

$\mathrm{ABTS}^{\cdot+}$ scavenging effect $\%=\left[\left(\mathrm{A}_{\mathrm{ABTS}}{ }^{\cdot+}-\mathrm{As}_{\mathrm{S}}\right) / \mathrm{A}_{\mathrm{ABTS}}{ }^{\cdot+}\right] \times 100$ 
Where $\mathrm{A}_{\mathrm{S}}$ is the absorbance of remaining concentration of $\mathrm{ABTS}^{\cdot+}$ in the presence of sample and $\mathrm{A}_{\mathrm{ABTS}}{ }^{\circ+}$ is the initial concentration of the $\mathrm{ABTS}^{\circ+}$.

\subsection{Determination of Total Phenolic Concentrations}

The concentrations of total phenolic content in L. nobilis leaf were expressed as microgrammes of pyrocatechol equivalents (PEs), determined with Folin-Ciocalteu reagent (FCR) [27]. The sample solution (1 mL) dissolved in methanol was added to distilled water (46 $\mathrm{mL})$ and FCR $(1 \mathrm{~mL})$, and mixed thoroughly, $2 \%$ sodium carbonate $(3 \mathrm{~mL})$ were added to the mixture in $3 \mathrm{~min}$ and shaken intermittently for $2 \mathrm{~h}$ at room temperature. The absorbance was measured at $760 \mathrm{~nm}$. The concentration of phenolic compounds was calculated according to the following equation that was obtained from standard pyrocatechol graph: Absorbance $=0.0073 \mathrm{x}$ $-0.1665, r^{2}=0.9976$

\subsection{Determination of Total Flavonoid Concentrations}

Measurements of total flavonoid concentration of the extracts were based on the previously reported method [24], and results were expressed as quercetin equivalents (QEs). An aliquot of the sample solution $(1 \mathrm{~mL})$ extracts in methanol was mixed with $10 \%$ aluminum nitrate $(0.1 \mathrm{~mL}), 1 \mathrm{M}$ potassium acetate $(0.1 \mathrm{~mL})$ and $80 \%$ methanol $(3.8 \mathrm{~mL})$ in test tubes, and then the absorbance was measured at $415 \mathrm{~nm}$ in $40 \mathrm{~min}$, and stayed at room temperature. The concentrations of flavonoid compounds were calculated according to following equation that was obtained from the standard quercetin graph: Absorbance $=0.0082 \mathrm{x}+0.0073, \mathrm{r}^{2}=0.9998$.

\subsection{Preparation of Lotion}

The lotion was prepared by following steps. The ingredients; oils, purified water and poly(acrylic acid sodium salt) as emulsifier polymer blend, were weighed separately. $6 \mathrm{~g}$ of lilac-flavored hazelnut oil and $6 \mathrm{~g}$ of bay leaf volatile oil were added dropwise to $87 \mathrm{~mL}$ of purified water in a glass beaker at room temperature under magnetic stirring.

After the mixture was stirred with a magnetic stirrer for $10 \mathrm{~min}$, the formulation is completed by addition of the homogenized emulsifier polymer blend. After lotion preparation was completely homogenized, it was poured gently (to avoid the presence of bubbles) into a container.

\subsection{Stability Tests of Cosmetic Preparation}

\subsubsection{Determination of Viscosity}

The rheology analysis of the lotion formulation containing L. nobilis leaf volatile oil was performed using Brookfield LVDV -I+ viscometer at $10 \mathrm{rpm}, 25^{\circ} \mathrm{C}$. Rheological analyses were repeated 1, 5, 30 and 90 days after lotion preparation was completed.

\subsubsection{Centrifugation Assay}

The centrifuge test, which is often used for having preliminary information in the stability tests, was performed as described in [28]. The lotion sample was centrifuged twice; each was $15 \mathrm{~min}$ at $3000 \mathrm{rpm}$ and under ambient temperature. A $10 \mathrm{~mL}$ centrifuge tube was used for centrifugation and it was observed whether there was phase separation.

\subsection{3. pH Measurements}

$\mathrm{pH}$ change during storage is one of the indicator for chemical stability of cosmetic preparations. The $\mathrm{pH}$ of the skin care lotion was measured according to the method given in [29]. The measurement was performed at room temperature with a Sartorius $\mathrm{pH}$ meter after $1 / 10(\mathrm{v} / \mathrm{v})$ dilution of the sample with purified water and filtration. Before the measurement, the $\mathrm{pH}$ meter was calibrated with the standard buffer solution $(\mathrm{pH}=4,7$ and 10). 


\subsection{Organoleptic Tests of Cosmetic Preparation}

Cosmetic preparation was evaluated for appearance, color, odor and spreadability. A visual evaluation was made by adding the sample to a glass container, placed over a white background, and compared it to the previous observations. Spreadability of cosmetic preparation was evaluated according to the expressions of user. All of the organoleptic analyzes were carried out in the same light, temperature and packaging conditions to avoid variations in appearance, color, odor and spreadability parameters. All tests were repeated on 1, 5, 30 and 90 days after the product was prepared.

\section{RESULT AND DISCUSSION}

\subsection{Chemical Composition of Volatile Oil}

In this study, forty-eight components were detected in the volatile oil obtained from $L$. nobilis leaves by steam distillation (Table 1). Volatile oil analyzed by GC/MS instrument and 1,8-cineol (46.16\%), alpha-terpinyl acetate (10.62\%), alpha-pinene (6.27\%), terpinen-4-ol $(5.07 \%)$, sabinene $(4.99 \%)$ and beta-pinene $(4.47 \%)$ detected as major compounds among forty-eight components. The other compounds such as 3-hexen-1-ol $(0.03 \%)$, cis-beta-ocimene $(0.05 \%)$ and 2-methylprop-1-enyl-cyclohexa-1,3-diene $(0.07 \%)$ were minor compounds.

The chemical composition of L. nobilis volatile oil from different locations has been studied by different researchers. In all studies, 1,8-cineole was the major component with percentages ranging between $26.70 \%$ and $68.48 \%$ [14, 30]. Moreover, alpha-terpinyl acetate with percentages ranging between $0.65-25.70 \%[31,32]$ and terpinen-4-ol with percentages ranging between $1.50-4.56 \%[32,33]$ were found as major components. According to the our result, we found average amount of 1,8-cineol but terpinen-4-ol was found to be more than average amounts reported by previous researches (Figure 1).

Tanriverdi et al. [34] found that leaves of L. nobilis of Turkish origin contained 1,8cineole (62.64\%), alpha-pinene (3.14\%), and terpinen-4-ol (3.11\%). Riaz et al. [35] established that leaf oil of L. nobilis contained 1,8-cineole (44.12\%). Florini et. al. [36] from France reported that $L$. nobilis leaves volatile oil contained 1,8-cineole (39.10\%), linalool (10.00\%), $\beta$ caryophyllene $(1.60 \%)$, alpha-terpinyl acetate (18.20\%) and terpinene-4-ol (1.40\%) while Yalçı et. al. [37] found 1,8-cineole (58.59\%), alpha-terpinyl acetate (8.82\%), and terpinene$4-\mathrm{ol}(4.25 \%)$ as the main components of the essential oil isolated from the leaves of the $L$. nobilis plant (from the Northern Cyprus Mountains) by hydrodistillation.

Volatile oils have been used as antioxidants for the prevention of skin disorders such as skin cancer and wrinkles which caused by oxidative stress on skin surface [38]. 
Table 1. GC/MS analysis of volatile oil composition of Laurus nobilis leaf

\begin{tabular}{|c|c|c|c|c|}
\hline No & RT (min.) & Compound & Concentration (\%) & $\begin{array}{l}\text { Identification } \\
\text { method }\end{array}$ \\
\hline 1 & 3.656 & 3-Hexen-1-ol & 0.03 & $\mathrm{~b}, \mathrm{c}$ \\
\hline 2 & 5.707 & alpha-Thujene & 0.50 & $a, b, c$ \\
\hline 3 & 5.893 & alpha-Pinene & 6.27 & $a, b, c$ \\
\hline 4 & 6.089 & 2,4(10)-Thujadien & 0.08 & $\mathrm{~b}, \mathrm{c}$ \\
\hline 5 & 6.262 & Camphene & 0.75 & $a, b, c$ \\
\hline 6 & 7.116 & Sabinene & 4.99 & $a, b, c$ \\
\hline 7 & 7.209 & beta-Pinene & 4.47 & $a, b, c$ \\
\hline 8 & 7.902 & beta-Myrcene & 0.30 & $a, b, c$ \\
\hline 9 & 8.301 & alpha-Phellandrene & 0.27 & $a, b, c$ \\
\hline 10 & 8.627 & 3-Carene & 0.08 & $\mathrm{~b}, \mathrm{c}$ \\
\hline 11 & 8.849 & alpha-Terpinene & 0.82 & $a, b, c$ \\
\hline 12 & 8.984 & o-Cymene & 2.61 & $a, b, c$ \\
\hline 13 & 9.394 & 1,8-Cineol & 46.16 & $\mathrm{a}, \mathrm{b}, \mathrm{c}$ \\
\hline 14 & 9.429 & alpha-Limonene & 1.90 & $a, b, c$ \\
\hline 15 & 10.369 & cis-beta-Ocimene & 0.05 & $a, b, c$ \\
\hline 16 & 10.732 & gamma-Terpinene & 1.48 & $a, b, c$ \\
\hline 17 & 10.883 & trans-Sabinene hydrate & 0.16 & $\mathrm{~b}, \mathrm{c}$ \\
\hline 18 & 11.885 & Unknown & 0.08 & $a, b, c$ \\
\hline 19 & 12.190 & alpha-Terpinolene & 0.33 & $a, b, c$ \\
\hline 20 & 12.349 & cis-Sabinene hydrate & 0.12 & $\mathrm{~b}, \mathrm{c}$ \\
\hline 21 & 12.733 & Linalool & 1.43 & $a, b, c$ \\
\hline 22 & 13.598 & p-Ment-2-en-1-ol & 0.18 & $\mathrm{~b}, \mathrm{c}$ \\
\hline 23 & 14.305 & trans-Pinocarveol & 0.41 & $\mathrm{~b}, \mathrm{c}$ \\
\hline 24 & 15.115 & (E)-Sabinen hydrate & 0.26 & $\mathrm{~b}, \mathrm{c}$ \\
\hline 25 & 16.630 & Terpinen-4-ol & 5.07 & $a, b, c$ \\
\hline 26 & 16.861 & Myrtenal & 0.26 & $\mathrm{~b}, \mathrm{c}$ \\
\hline 27 & 17.052 & beta-Phellandren-8-ol & 0.12 & $\mathrm{~b}, \mathrm{c}$ \\
\hline 28 & 17.174 & p-Mentha-1(7),8-dien-2-ol & 0.10 & $\mathrm{~b}, \mathrm{c}$ \\
\hline 29 & 17.308 & alpha-Terpineol & 2.17 & $a, b, c$ \\
\hline 30 & 17.553 & Estragole & 0.06 & $\mathrm{~b}, \mathrm{c}$ \\
\hline 31 & 17.669 & Myrtenol & 0.41 & $a, b, c$ \\
\hline 32 & 18.428 & cis-Piperitol & 0.08 & $\mathrm{~b}, \mathrm{c}$ \\
\hline 33 & 22.663 & 4-Thujen-2-alpha-YL & 0.26 & $\mathrm{~b}, \mathrm{c}$ \\
\hline 34 & 23.120 & Bornyl acetate & 0.63 & $a, b, c$ \\
\hline 35 & 25.067 & Unknown & 0.67 & \\
\hline 36 & 25.533 & 1-ethyl-3,5-dimethyl-benzene & 0.09 & $\mathrm{~b}, \mathrm{c}$ \\
\hline 37 & 26.600 & 2-Methylprop-1-enyl cyclohexa 1,3-diene & 0.07 & $\mathrm{~b}, \mathrm{c}$ \\
\hline 38 & 26.817 & Eugenol & 1.18 & $\mathrm{~b}, \mathrm{c}$ \\
\hline 39 & 27.176 & alpha-Terpinyl acetate & 10.62 & $a, b, c$ \\
\hline 40 & 28.230 & Unknown & 0.09 & \\
\hline 41 & 29.758 & Eugenol methyl ether & 3.24 & $b, c$ \\
\hline 42 & 30.106 & beta-Elemene & 0.10 & $\mathrm{~b}, \mathrm{c}$ \\
\hline 43 & 31.395 & beta-Caryophyllene & 0.12 & $a, b, c$ \\
\hline 44 & 31.785 & Cinnamyl acetate & 0.28 & $\mathrm{~b}, \mathrm{c}$ \\
\hline 45 & 35.047 & Isoeugenyl methyl ether & 0.17 & $\mathrm{~b}, \mathrm{c}$ \\
\hline 46 & 39.688 & Spathulenol & 0.19 & $\mathrm{~b}, \mathrm{c}$ \\
\hline 47 & 39.842 & Caryophyllene oxide & 0.22 & $\mathrm{a}, \mathrm{b}, \mathrm{c}$ \\
\hline 48 & 42.754 & beta-Eudesmol & 0.10 & $\mathrm{~b}, \mathrm{c}$ \\
\hline
\end{tabular}

${ }^{\mathrm{a} C}$ Comparison with standard compounds, ${ }^{\mathrm{b}} \mathrm{GC} / \mathrm{MS}$ analysis, ${ }^{\mathrm{c}}$ Literature comparison 


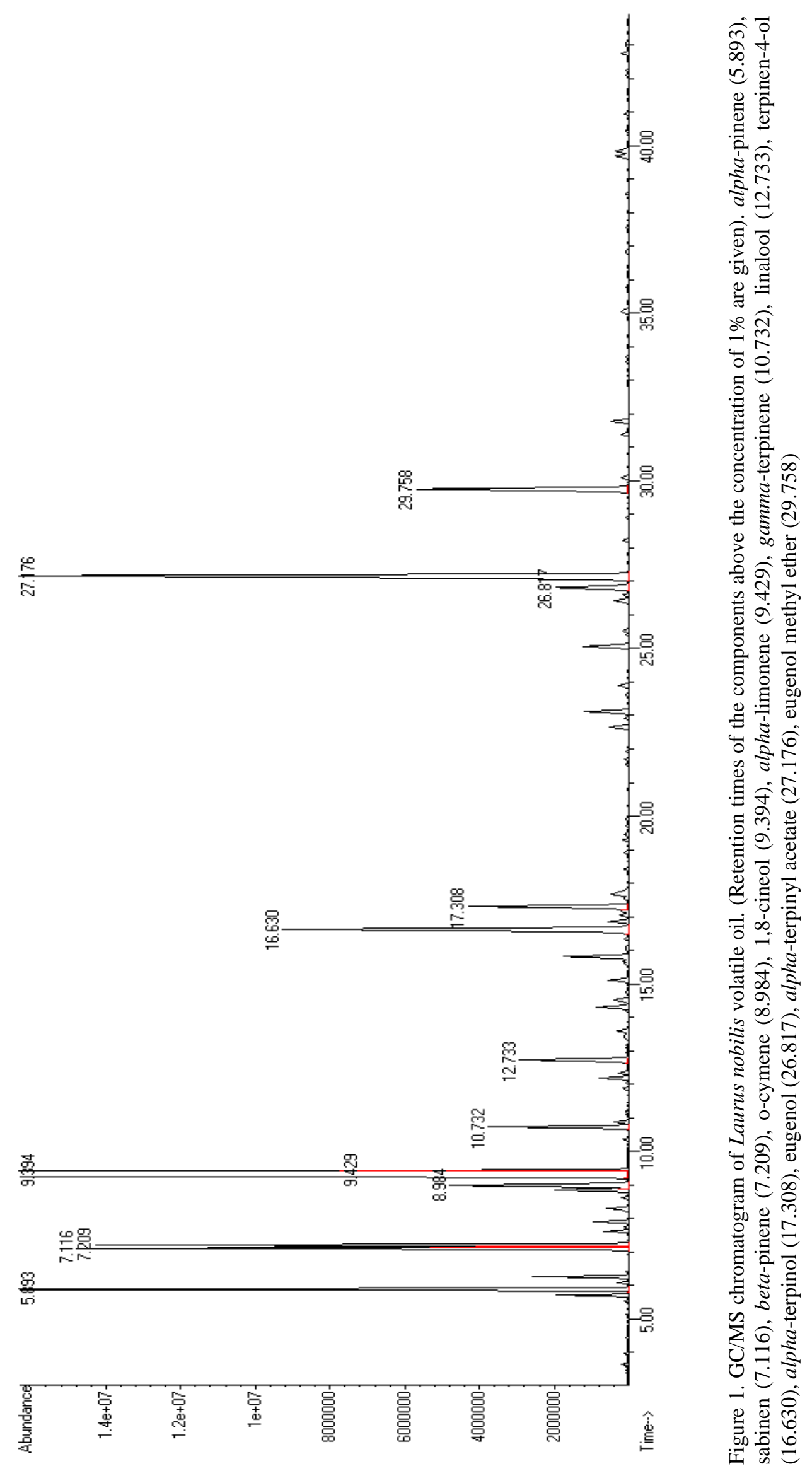


High amount of 1,8-cineol (46.16\%) and terpinen-4-ol (5.07\%) makes volatile oil a potent of cosmetic ingredient due to their high antioxidant activity [39]. However, these compounds described as potent of antifungal agent by previous researches [40] and with this reason they can be considered as self-preserving ingredient for cosmetic products.

Considering the proven effects of $L$. nobilis leaf volatile oil and previous studies, the use of $L$. nobilis leaf essential oil in cosmetic formulations can result in high added value to the product and contribute to product functionality.

\subsection{Antioxidant Activities}

Antioxidant activities of extracts from L. nobilis leaves were investigated using three different methods ( $\beta$-carotene-linoleic acid, $\mathrm{ABTS}^{\circ}$ and $\left.\mathrm{DPPH}^{\circ}\right)$. The antioxidant activities of L. nobilis leaf extracts were measured by using spectrophotometric methods after they were dissolved in appropriate solvents. When the total antioxidant activity values were examined, the $50 \%$ inhibition concentration $\left(\mathrm{IC}_{50}\right)$ of ethyl acetate extract was found to be $19.32 \pm 1.04 \mu \mathrm{g}$ $\mathrm{mL}^{-1}$ in the $\beta$-carotene-linoleic acid assay. Compared to the other extracts and standards, ethyl acetate extract seems to be quite active.

In addition, according to the results of $\mathrm{ABTS}^{\cdot+}$ cation radical and $\mathrm{DPPH}^{\circ}$ free radical scavenging assays, ethyl acetate extract was found to be the most active extract, respectively $\left(24.98 \pm 0.87 \mu \mathrm{g} \mathrm{mL}^{-1}\right.$ and $\left.75.65 \pm 0.77 \mu \mathrm{g} \mathrm{mL}^{-1}\right)$. DPPH free radical inhibition $\mathrm{IC}_{50}$ value of ethyl acetate extract of $L$. nobilis leaves was found to be $75.65 \pm 0.77 \mu \mathrm{g} \mathrm{mL}^{-1}$, whereas butylated hydroxytoluene (BHT) $\mathrm{IC}_{50}$ value, used as standard, was $68.27 \pm 0.67 \mu \mathrm{g} \mathrm{mL}^{-1}$ (Table 2).

Table 2. Antioxidant activity of the extracts of L. nobilis by $\beta$-carotene-linoleic acid, $\mathrm{ABTS}^{\cdot+}$ and $\mathrm{DPPH}^{*}$ assays

\begin{tabular}{|c|c|c|c|c|}
\hline & \multirow{3}{*}{ Extracts } & \multicolumn{3}{|c|}{ Antioxidant activity } \\
\hline & & $\beta$-Carotene-linoleic acid & $\mathrm{ABTS}^{\bullet+}$ assay & $\mathrm{DPPH}^{\circ}$ assay \\
\hline & & assay $\mathrm{IC}_{50}\left(\mu \mathrm{g} \mathrm{mL} L^{-1}\right)$ & $\mathrm{IC}_{50}\left(\mu \mathrm{g} \mathrm{mL}^{-1}\right)$ & $\mathrm{IC}_{50}\left(\mu \mathrm{g} \mathrm{mL}^{-1}\right)$ \\
\hline \multirow{4}{*}{$\begin{array}{l}\text { Laurus } \\
\text { nobilis }\end{array}$} & Hexane & $47.08 \pm 0.20$ & $55.34 \pm 1.21$ & $201.47 \pm 0.60$ \\
\hline & Ethyl acetate & $19.32 \pm 1.04$ & $24.98 \pm 0.87$ & $75.65 \pm 0.77$ \\
\hline & Ethanol & $36.23 \pm 1.01$ & $43.74 \pm 0.57$ & $129.10 \pm 0.66$ \\
\hline & Water & $124.01 \pm 1.65$ & $99.75 \pm 1.41$ & $203.55 \pm 0.98$ \\
\hline \multirow{3}{*}{ Standards } & BHA & $2.18 \pm 0.09$ & $6.28 \pm 0.10$ & $67.40 \pm 0.41$ \\
\hline & BHT & $2.05 \pm 0.11$ & $6.37 \pm 0.08$ & $68.27 \pm 0.67$ \\
\hline & $\alpha$-Tocopherol & $3.87 \pm 0.15$ & $6.97 \pm 0.13$ & $10.41 \pm 0.19$ \\
\hline
\end{tabular}

$\mathrm{IC}_{50}$ values represent the means $\pm \mathrm{SD}$ of three parallel measurements

BHA; Butylated hydroxyanisole, BHT; Butylated hydroxytoluene

Number of studies have been done to evaluate the antioxidant properties of different extracts of $L$. nobilis leaves. Previous researchers have reported that ethanolic extract of $L$. nobilis leaves exhibited an $\mathrm{IC}_{50}$ value of $22 \pm 0.531 \mu \mathrm{g} \cdot \mathrm{mL}^{-1}$ using by DPPH ${ }^{\bullet}$ assay and $1 \pm$ $0.315 \mu \mathrm{g} . \mathrm{mL}^{-1}$ according to $\beta$-carotene-linoleic acid assay [41]. In another study, ethyl acetate extract and water extract of $L$. nobilis leaves exhibited an $\mathrm{IC}_{50}$ value of $83.24 \mu \mathrm{g} . \mathrm{mL}^{-1}$ and $161.83 \mu \mathrm{g} \cdot \mathrm{mL}^{-1}$, respectively, using by $\mathrm{DPPH}^{*}$ assay [42]. More studies in the literature indicated that leaf extracts of $L$. nobilis provide significant antioxidant effect $[43,44]$. Our results are compatible with the literature with respect to antioxidant effect. 


\subsection{Total Phenolic and Flavonoid Concentrations}

Amounts of total phenolic and flavonoid contents in extracts of L. nobilis leaves are given in Table 3. The highest amount of total phenolic content with the amount of $54.42 \pm 0.14 \mu \mathrm{g}$ $\mathrm{PEs} / \mathrm{mg}$ extract was determined in ethyl acetate extract of $L$. nobilis leaves and the minimum total phenolic content with the amount of $11.04 \pm 0.20 \mu \mathrm{g}$ PEs/mg extract was measured in water extract of leaves. According to the results of total flavonoid content assessments of extracts, the highest total flavonoid content was found in ethanol extract $(8.60 \pm 0.12 \mu \mathrm{g}$ QEs/mg extract) and the lowest flavonoid content was determined in the hexane extract $(1.01 \pm 0.10 \mu \mathrm{g}$ QEs $/ \mathrm{mg}$ extract) of L. nobilis leaves.

When we compared the results obtained, there is a good correlation between high antioxidant activity and high amount of phenolic compounds in extracts [45]. In previous studies, some researchers have found such positive correlations between antioxidant activity and the amount of phenolic compounds of plants [46, 47].

Table 3. Total phenolic and flavonoid concentrations of L. nobilis leaf extracts

\begin{tabular}{llcc}
\hline & Extracts & $\begin{array}{c}\text { Total Phenolic Content } \\
(\mu \mathrm{g} \text { PEs/mg extract })\end{array}$ & $\begin{array}{c}\text { Total Flavonoid Content } \\
(\mu \mathrm{g} \text { QEs/mg extract })\end{array}$ \\
\hline \multirow{3}{*}{ Laurus nobilis } & Hexane & $12.80 \pm 0.35$ & $1.01 \pm 0.10$ \\
& Ethyl acetate & $54.42 \pm 0.14$ & $5.48 \pm 0.65$ \\
& Ethanol & $25.32 \pm 0.10$ & $8.60 \pm 0.12$ \\
& Water & $11.04 \pm 0.20$ & $1.07 \pm 0.10$ \\
\hline
\end{tabular}

Results expressed as mean \pm standard deviation.

The ethanol and ethyl acetate extracts obtained by the subsequent extraction appear to be rich in phenolic and flavonoid content in both extracts. Ethyl acetate extracts rich in phenolic compounds were found to have highest antioxidant activity in three different methods ( $\beta$ carotene-linoleic acid, ABTS $^{\cdot+}$ and $\left.\mathrm{DPPH}^{*}\right)$.

Based on the results, it can be said that phenolic compounds have an important effect on the antioxidant activities of extracts. In addition to the phenolic concentrations of extracts, flavonoid concentrations of $L$. nobilis leaf extract were investigated. The total amount of flavonoid contents in the ethyl acetate and ethanol extracts with high amounts of phenolic contents were found to be $5.48 \pm 0.65$ and $8.60 \pm 0.12 \mu \mathrm{g}$ QEs/mg extract, respectively.

\subsection{Stability and Organoleptic Tests of Cosmetic Preparation}

The results obtained from the stability tests and the organoleptic analyses of the cosmetic formulation made by the cold process following the analysis are given in Table 4 . No phase separation was observed in both 15 min analyzes performed on the days 1, 5, 30 and 90 in centrifugation tests. The $\mathrm{pH}$ measurements made on the formulation showed that there was no significant change in the $\mathrm{pH}$ of the lotion even after 90 days. Only very small changes due to time have been identified. The viscosity of the product has changed to negligible level due to very small $\mathrm{pH}$ changes and it maintains product stabilization after 90 days.

The product was homogeneous and easy to spread when it was prepared. Lotion left a soft, non-greasy feel after it was subjected. There was no change in the product's spreadability and appearance after 90 days. 
Table 4. Results of stability tests and organoleptic analysis of formulation

\begin{tabular}{cllll}
\hline Test / Time & 1st day & 5th day & 30th day & 90th day \\
\hline Stability Tests & & & & \\
\hline$p H$ & 5.86 & 5.87 & 5.90 & 5.95 \\
Viscosity(cPs) & 14400 & 14460 & 14465 & 14502 \\
Centrifuge & Stable & Stable & Stable & Stable \\
\hline Organoleptic Tests & & & & \\
\hline Appearance & Homogeneous & Homogeneous & Homogeneous & Homogeneous \\
Color & Greeny white & Greeny white & Greeny white & Greeny white \\
Odor & Laurel odor & Laurel odor & Laurel odor & Laurel odor \\
Spreadability & Easy & Easy & Easy & Easy \\
\hline
\end{tabular}

\section{CONCLUSION}

Nowadays, it is clear to see that the escape from artificial substances will further increase the importance of natural products. With this reason, investigation of composition and biological activities of natural substances is important. In this study, the volatile oil composition of L. nobilis leaves was accurately determined by comparative methods using GC/MS instrument. According to the our results, the amounts of 1,8-cineol, alpha-terpinyl acetate and alpha-pinene are similar to the previous studies made by different researchers. However, the amount of terpinen-4-ol in this study found to be higher than other studies.

The antioxidant potential of the extracts was determined using three complementary methods. The extracts investigated in this study have significant antioxidant activity. The highest antioxidant activity in all assays (DPPH, ABTS, $\beta$-carotene) was measured in ethyl acetate extract of $L$. nobilis leaf extract.

L. nobilis volatile oil has potency in cosmetic products due to its numerous antioxidant components. At present, the cosmetic formulation formed within the scope of the study has passed successfully the stability and organoleptic tests that were carried out. At the end of 90 days, there was no significant change in the $\mathrm{pH}$ and viscosity parameters of the formulation, and no change in organoleptic properties, such as product appearance, color, odor, spreadability were observed. Good stabilization of the formulation proves that the volatile oil has successfully performed its mission of acting as a preservative in the cosmetic formulation.

In the next step of the study, various dermo-cosmetic effects can be examined of the prepared formulation, and the obtained oil can be used on the formulations in different types of cosmetic products.

\section{REFERENCES}

[1]. Carvalho I.T., Estevinho B. N., Santos L. (2015) Application of microencapsulated essential oils in cosmetic and personal healthcare products-a review, International Journal of Cosmetic Science, 38(2): 109-119.

[2]. Do T., Hadji-Minaglou F., Antoniotti S., Fernandez X. (2015) Authenticity of essential oils, Trends in Analytical. Chemistry, 66:146-157.

[3]. Bakkali F., Averbeck S., Averbeck D., Idaomar M. (2008) Biological effects of essential oils - a review, Food and Chemical Toxicology, 46(2): 446-745. 
[4]. Sell C. (2010) Chemistry of essential oils. In: Baser K.H.C., Buchbauer G. (Eds.), Handbook of Essential Oils. Boca Raton: CRC Press.

[5]. Ríos J. (2016) Essential Oils: What They Are and How the Terms Are Used and Defined. In: Preedy V.R. (ed.) Essential Oils in Food Preservation, Flavor and Safety. USA: Academic Press.

[6]. Sonwa M. (2000) Isolation and Structure Elucidation of Essential Oil Constituents. Comparative Study of the Oils of Cyperus alopecuroides, Cyperus papyrus, and Cyperus rotundus, Ph.D. degree, University of Hamburg, Germany.

[7]. Chamorro E.R., Zambón S.N., Morales W.G., Sequeira A.F., Velasco G.A. (2012). Study of the chemical composition of essential oils by gas chromatography. In: Salih B., Çelikbıçak Ö. (Eds.), Gas Chromatography in Plant Science, Wine Technology, Toxicology and Some Specific Applications. Rijeka: InTech.

[8]. Zellner B.A., Dugo P., Dugo G., Mondello L. (2010) Analysis of essential oils. In: Baser K.H.C., Buchbauer G. (Eds.), Handbook of Essential Oils, Science, Technology and Applications. Boca Raton: CRC Press.

[9]. Preedy V.R (ed.) (2016) Essential Oils in Food Preservation, Flavor and Safety. USA: Academic Press.

[10]. Kolar M.H., Urbancic S., Dimitrijevic D. (2009) Nutritional Cosmetics. Burlington: Elsevier.

[11]. Raut J.S., Karuppayil S.M. (2014) A status review on the medicinal properties of essential oils, Industrial Crops and Products, 62: 250-264.

[12]. Dall'Acqua S., Viola G., Giorgetti M., Loi M.C., Innocenti G. (2006) Two new sesquiterpene lactones from the leaves of Laurus nobilis, Chemical and Pharmaceutical Bulletin, 54(8): 1187-1189.

[13]. Sayyah M., Saroukhani G., Peirovi A., Kamalinejad M. (2003) Analgesic and antiinflammatory activity of the leaf essential oil of Laurus nobilis Linn., Phytotherapy Research, 17(7): 733-736.

[14]. Ozcan M., Chalchat J.C. (2005) Effect of different locations on the chemical composition of essential oils of laurel (Laurus nobilis L.) leaves growing wild in Turkey, Journal of Medicinal Food, 8(3): 408-411.

[15]. Basak S.S., Candan F. (2013) Effect of Laurus nobilis L. essential oil and its main components on $\alpha$-glucosidase and reactive oxygen species scavenging activity, Iranian Journal of Pharmaceutical Research, 12(2): 367-379.

[16]. Sayyah M., Valizadeh J., Kamalinejad M. (2002) Anticonvulsant activity of the leaf essential oil of Laurus nobilis against pentylenetetrazole and maximal electroshockinduced seizures, Phytomedicine. 9(3): 212-216.

[17]. Loizzo M.R, Saab A.M., Tundis R., Statti G.A., Menichini F., Lampronti I., Gambari R., Cinatl J., Doerr H.W. (2008) Phytochemical analysis and in vitro antiviral activities of the essential oils of seven Lebanon species, Chemistry and Biodiversity. 5(3): 461-470.

[18]. Ferreira A., Proenca C., Serralheiro M.L.M., Araujo M.E.M. (2006) The in vitro screening for acetylcholinesterase inhibition and antioxidant activity of medicinal plants from Portugal, Journal of Ethnopharmacology, 108(1): 31-37.

[19]. Ozcan B., Esen M., Sangun M., Coleri A., Caliskan M. (2010) Effective antibacterial and antioxidant properties of methanolic extract of Laurus nobilis seed oil, Journal of Environmental Biology, 31(5): 637-641.

[20]. Corato D.U., Trupo M., Leone G.P., Sanzo D.G., Zingarelli G., Adami M. (2007) Antifungal activity of the leaf extracts of laurel (Laurus nobilis L.), orange (Citrus sinensis 
Osbeck) and olive (Olea europaea L.) obtained by means of supercritical carbon dioxide technique, Journal of Plant Pathology, 89(3): 83-91.

[21]. Hafizoğlu H., Reunanen M. (1993) Studies on the components of Laurus nobilis from Turkey with special reference to laurel berry fat, European Journal of Lipit Science and Technology, 95(8):304-308.

[22]. Muyima N.Y.O., Zulu G., Bhengu T., Popplewell D. (2002) The potential application of some novel essential oils as natural cosmetic preservatives in a aqueous cream formulation. Flavour Fragrance.Journal, 17(4): 258-266.

[23]. Brand-Williams W., Cuvelier M.E., Berset C. (1995) Use of free radical method to evaluate antioxidant activity, LWT Food Sceince and Technology, 28(1): 25-30.

[24]. Kivrak I., Duru M.E., Öztürk M., Mercan N,, Harmandar M., Topçu G. (2009) Antioxidant, Anticholinesterase and antimicrobial constituents from the essential oil and ethanol extract of Salvia potentillifolia, Food Chemistry, 116: 470-479.

[25]. Miller HE (1971) A simplified method for the evaluation of antioxidants, Journal of American Oil Chemists Society, 48(2): 91-91.

[26]. Re R., Pellegrini N., Proteggente A., Pannala A., Yang M., Rice-Evans C. (1999) Antioxidant activity applying an improved ABTS radical cation decolorization assay, Free Radical Biology and Medicine, 26(9-10): 1231-1237.

[27]. Slinkard K., Singleton V.L. (1977) Total phenol analysis automation and comparison with manual methods, American Journal of Enology and Viticulture, 28(1): 49-55.

[28]. Arsic I., Zugic A., Tadic V., Tasic-Kostov M., Misic D., Primorac M., Runjaic-Antic D. (2012) Estimation of dermatological application of creams with St. John's Wort oil extracts, Molecules, 17: 275-294.

[29]. Heberle G., Dos Santos M.A., Magrı S. (2012) Cosmetic formulations containıng blueberry extracts (Vaccinıum Myrtillus L.), The Online Journal of Science and Technology, 2(1): 1-6.

[30]. Pino J., Borges P., Roncal E. (1993) The chemical composition of laurel leaf oil from various origins, Die Nahrung, 37(6): 592-595.

[31]. Sangun M.K., Aydın E., Timur M., Karadeniz H., Çalışkan M., Özkan A. (2007) Comparison of chemical composition of the essential oil of Laurus nobilis leaves and fruits from different regions of hatay, Turkey, Journal of Environmental Biology, 28(4): 731-733.

[32]. Sellami I.H., Wannes W.A., Bettaieb I., Berrima S., Chahed T., Marzouk B., Limam F. (2011) Qualitative and quantitative changes in the essential oil of Laurus nobilis L. leaves as affected by different drying methods, Food Chemistry, 126(2): 691-697.

[33]. Lira P.D.L., Rettaa D., Tkacik E., Ringuelet J., Coussio J.D., van Baren C., Bandoni A.L. (2009) Essential oil and by-products of distillation of bay leaves (Laurus nobilis L.) From argentina, Industrial Crops and Products, 30(2): 259-264.

[34]. Tanrıverdi H., Özek T., Beis H., Baser K.H.C. (1992) Composition of the essential oil of Turkish laurel leaves and berries. In: Felicitation Volume on the 50th Birthday of Prof. Atta-Ur-Rahman, Hamdard Foundation. Karachi: MAS Printers.

[35]. Riaz M., Ashraf C.M., Chaudhary F.M. (1989) Studies of the essential oil of the Pakistani Laurus nobilis Linn in different seasons, Pakistan Journal of Scientific and Industrial Research, 32(1):33-35.

[36]. Fiorini C., Fourasté I., David B., Bessière J. M. (1997) Composition of the Flower, Leaf and Stem Essential Oils from Laurus nobilis, Flavour and Fragrance Journal, 12(2): 9193. 
[37]. Yalçın H., Anık M., Şanda M.A., Çakır A. (2007) Gas Chromatography/Mass Spectrometry Analysis of Laurus nobilis Essential Oil Composition of Northern Cyprus, Journal of Medicinal Food, 10(4): 715-719.

[38]. Wei A., Shibamoto T. (2007) Antioxidant activities of essential oil mixtures toward skin lipid squalene oxidized by UV irradiation, Cutaneous and Ocular Toxicology, 26(3): 227233.

[39]. Lee K.G., Shibamoto T. (2001) Antioxidant activities of volatile components isolated from Eucalyptus species, Journal of the Science of Food and Agriculture, 81(15): 15731579 .

[40]. Morcia C., Malnati M., Terzi V. (2012) In vitro antifungal activity of terpinen-4-ol, eugenol, carvone, 1,8-cineole (eucalyptol) and thymol against mycotoxigenic plant pathogens, Food Additives \& Contaminants: Part A, 29(3): 415-422.

[41]. Conforti F., Statti G., Uzunov D., Menichini F. (2016) Comparative Chemical Composition and Antioxidant Activities of Wild and Cultivated Laurus nobilis L. Leaves and Foeniculum vulgare subsp. Piperitum (Ucria) Coutinho Seeds, Biological and Pharmaceutical Bulletin, 29(10): 2056-2064.

[42]. Kaurinovic B., Popovic M., Vlaisavljevic S. (2010) In Vitro and In Vivo Effects of Laurus nobilis L. Leaf Extracts, Molecules, 15(5): 3378-3390.

[43]. Dias M.I., Barros L., Dueñas M., Alves R.C., Oliveira M.B.P.P., Santos-Buelga C., Ferreira I.C.F.R. (2014) Nutritional and antioxidant contributions of Laurus nobilis L. leaves: Would be more suitable a wild or a cultivated sample?, Food Chemistry, 156(1): 339-346.

[44]. Ferreira A., Proenc C., Serralheiro M.L.M., Araujo M.E.M. (2006) The in vitro screening for acetylcholinesterase inhibition and antioxidant activity of medicinal plants from Portugal, Journal of Ethnopharmacology, 108(1): 31-37.

[45]. Aydın Ç., Özay C., Düşen O., Mammadov R., Orhan F. (2017) Total Phenolics, Antioxidant, Antibacterial and Cytotoxic Activity Studies of Ethanolic Extracts Arisarum vulgare O.Targ.Tozz. and Dracunculus vulgaris Schott, International Journal of Secondary Metabolite, 4(2): 114-122.

[46]. Kivrak I. (2015) Analytical Methods Applied to Assess Chemical Composition, Nutritional Value and In Vitro Bioactivities of Terfezia olbiensis and Terfezia claveryi from Turkey, Food Analytical Methods, 8(5): 1279-1293.

[47]. Mammadov R., Ili P., Düşen O. (2012) Phenolic Contents and Antioxidant Properties of Muscari parviflorum Desf., Journal of the Chemical Society of Pakistan, 34(3): 651-655. 